\title{
DIGITAL SKILLS AND COMPETENCES IN BUSINESS STUDENTS IN A COVID-19 LOCKDOWN SCENARIO
}

\author{
Helena Mogorrón Guerrero ${ }^{1 *}$, María Orero Blat ${ }^{2}$, Virginia Simón Moya ${ }^{3}$, María \\ Guijarro García ${ }^{4}$ \\ ${ }^{1}$ Prof. Helena Mogorrón Guerrero, ESIC Business \& Marketing School, SPAIN, \\ helena.mogorron@esic.edu \\ ${ }^{2}$ Ms. María Orero Blat, Universidad Politécnica de Valencia, SPAIN, morebla@doctor.upv.es \\ ${ }^{3}$ Dr. Virginia Simón Moya, Universidad de Valencia, SPAIN, virginia.simon@uv.es \\ ${ }^{4}$ Prof. María Guijarro García, ESIC Busines \& Marketing School, SPAIN, maria.guijarro@esic.edu \\ ${ }^{*}$ Corresponding Author
}

\begin{abstract}
After the global crisis derived from COVID-19, all professional and personal areas have been forced to evolve, in order to adapt to this new context. Education has been one of the areas that has had to know how to adapt to this paradigm the fastest, integrating technology as the basis and main tool in the educational process. From this fact, the main objective of our study was born, with the aim of knowing, after a survey carried out among students of three degrees and three different masters in a prestigious Spanish business school, how this situation has affected the development of their skills and digital skills, as well as the main differentiating elements that can influence a greater or lesser adaptation. A methodological proposal is presented for the treatment of the data and the future validation of the scale, as well as future expected conclusions that derive from this study, which are: a greater development of these skills by the students of the master's degrees due to greater use of computer applications in the academic world, greater capacity for adaptation and autonomous learning, and a higher average grade in comparison with the degrees.
\end{abstract}

Keywords: digital competences, transformative learning, lockdown education, technological skills

\section{INTRODUCTION}

In today's knowledge economy, it is often claimed that the hope for growth, innovation, and the ability to compete will come from a highly tech-skilled workforce (Riel \& Hinson, 2012; Orero-Blat, Simón-Moya, Mogorrón-Guerrero, Botella-Carrubi \& Sendra, J., 2020). Currently, the COVID-19 crisis has affected all areas, both professional and personal globally. This fact has forced society to an adaptive evolution of a 
technological nature to this new context, in which uncertainty has been the main question (livari, Sharma \& Ventä-Olkkonen, 2020), and giving the adaptation process a big role in every institution, person and society.

Within this new paradigm, the educational community has been one of those that have had to carry out a faster and more forceful action plan, with the aim of being able to carry out its activity and its dynamics in the best possible way. It has gone from a face-to-face educational environment almost in its entirety, to distance education without any type of physical contact nor touchable tools or sources. Therefore, both students and teachers have found it necessary to develop digital skills and competencies that allow them to adapt to this new environment (Battro, 2004).

Likewise, not only are these digital skills necessary in education, but in the current knowledge economy, these skills are also related to innovation and the ability to compete with a workforce with high technological capabilities (Riel \& Hinson, 2012). This fact, together with globalization, means that current education is not only centered between quality and quantity, but also adapted to local and global issues (Lara, MogorrónGuerrero, \& Ribeiro-Navarrete, 2020).

This is where the objectives of our paper reside, which are to know what the digital skills have been developed in the students of a Spanish business school, as well as the relationship they may have with the variables to be analyzed in the study. It is also in this new context where our research gap is born, which is the discovery of the digital skills and competencies developed in business students in a scenario derived from the current crisis derived from COVID-19. For this reason, we present this paper in an exploratory way and with a research proposal and methodological approach, in order to receive feedback before proceeding with its complete preparation for publication.

The structure of this paper is organized as it follows: first, we find the review of the literature on digital skills and competences. After that, the methodology to be used, which is an experimental scale that has to be validated later. Third, the expected conclusions that will result from the study are presented, also exhibiting the limitations and future steps to follow in this research.

\section{LITERATURE REVIEW}

In this section of literature review the authors will address a review of several well-known literature on the subjects of digital competences and Internet skills, plus their measurement using different scales and rubrics. This will allow a complete overview on the topic in order to distinguish concepts and be able to continue with the methodology and discussions sections.

The concept of 'digital skills' has been widely defined in academia but scholars have not accepted a final definition yet (Vieru, 2015). The first studies on digital competences date back to 1995 when a Norwegian university published its case study of online education through video calls (Spongberg, 1995). Since then, different investigations have been published in the field of education, especially and in recent years applied to the field of business. In 2007 the European Union published a recommendation in which Eight Competences for Lifelong Learning were identified. Digital Literacy was also included, as a broader concept than digital skills or competence (Morrison \& Rooney, 2017). Dhiman \& Arora (2020) recently contributed in the field of employee branding to defining the scope of digital and internet capabilities.

The most accepted definition since today is the one by Ferrari $(2012$, p.2) in which states that the term digital competence is 'the set of knowledge, skills, attitudes, abilities, strategies and awareness that are required when using ICT and digital media work and behave in current society. Some daily routines are: to perform tasks; solve problems; communicate; manage information; collaborate; create and share content; build knowledge effectively, efficiently, appropriately, critically, creatively, autonomously, flexibly, ethically, reflectively for work, leisure, participation, learning, socialising, consuming and empowerment'.

Digital competences could be measured according different scales and rubrics. Below we observe an example in a report by Gekara et al., (2019) (Table 1) in which digital skills of Australian workforce were measured. Here, the authors divide the level of need or performance of different approaches in digital skills in five levels: 1 literacy, 2 competence, 3 proficiency, 4 fluency and 5 savy. However, no scales have been yet validated in the literature. 
Table 1: Digital competences measurement

\begin{tabular}{|c|c|c|c|c|c|}
\hline \multirow{2}{*}{$\begin{array}{l}\text { Digital } \\
\text { skill } \\
\text { content }\end{array}$} & \multicolumn{5}{|c|}{ Level of need/ performance } \\
\hline & Literacy $(1)$ & Competency $\{2\rangle$ & Proficiency (3) & Fluency (4) & Sarvy (5) \\
\hline $\begin{array}{l}\text { Digital } \\
\text { tools for } \\
\text { working }\end{array}$ & $\begin{array}{l}\text { Understand } \\
\text { various digtal } \\
\text { tools }\end{array}$ & $\begin{array}{l}\text { Basic use of } \\
\text { vanious digital } \\
\text { tools }\end{array}$ & $\begin{array}{l}\text { Application of } \\
\text { advanced clg tal } \\
\text { tools cerfidently } \\
\text { and efficiently }\end{array}$ & $\begin{array}{l}\text { Evaluaile and } \\
\text { solect } \\
\text { appropriate } \\
\text { digital toals for } \\
\text { working }\end{array}$ & $\begin{array}{l}\text { Suggest } \\
\text { solutions, to } \\
\text { solve problems } \\
\text { in the use of } \\
\text { digilal tools }\end{array}$ \\
\hline
\end{tabular}

\begin{tabular}{|c|c|c|c|c|c|}
\hline $\begin{array}{l}\text { Digital } \\
\text { ways of } \\
\text { working }\end{array}$ & $\begin{array}{l}\text { Recegnise } \\
\text { various digtal } \\
\text { ways of working }\end{array}$ & $\begin{array}{l}\text { Basic ablity to } \\
\text { work digtaly such } \\
\text { as find, ratrews } \\
\text { and communicale } \\
\text { information from a } \\
\text { variety of } \\
\text { information } \\
\text { systems in a } \\
\text { variety of lormats }\end{array}$ & $\begin{array}{l}\text { Apply advanced } \\
\text { features to wark } \\
\text { dgealy such is to } \\
\text { search find, } \\
\text { retrieve, proocss } \\
\text { and communieate } \\
\text { infornation from } \\
\text { advanced systems }\end{array}$ & $\begin{array}{l}\text { Manage } \\
\text { (analyse, } \\
\text { compars, } \\
\text { evaluate) the } \\
\text { uscfulness, } \\
\text { relevarcy. } \\
\text { credibifity, and } \\
\text { relabilty } \alpha \\
\text { digitel ways of } \\
\text { working }\end{array}$ & $\begin{array}{l}\text { Identify and } \\
\text { articulale digital } \\
\text { wwys of warking } \\
\text { lssues; propose } \\
\text { aliernatives and } \\
\text { participate in the } \\
\text { implementation } \\
\text { of new ways of } \\
\text { working }\end{array}$ \\
\hline $\begin{array}{l}\text { Digital } \\
\text { ways of } \\
\text { thinking }\end{array}$ & $\begin{array}{l}\text { Awarences of } \\
\text { how to seek } \\
\text { suppert and } \\
\text { assistanos when } \\
\text { facing digital } \\
\text { prablems }\end{array}$ & $\begin{array}{l}\text { Ability to } \\
\text { communicase } \\
\text { problerns ralaled } \\
\text { to digital } \\
\text { processes, } \\
\text { rostires and } \\
\text { products }\end{array}$ & $\begin{array}{l}\text { Imwertigates digital } \\
\text { bushess } \\
\text { processes, } \\
\text { routrnas and } \\
\text { products through } \\
\text { an analytical and } \\
\text { 8ystematic } \\
\text { approuch to } \\
\text { probiem-8olving }\end{array}$ & $\begin{array}{l}\text { Analyse and } \\
\text { evaluate the } \\
\text { strengths and } \\
\text { weaknesses of } \\
\text { alternative } \\
\text { digitel } \\
\text { solutions, } \\
\text { cordusions or } \\
\text { gporoaches to } \\
\text { probicms }\end{array}$ & $\begin{array}{l}\text { Absorbs } \\
\text { camplex work } \\
\text { problems and } \\
\text { demanetrntes a } \\
\text { brosd and deep } \\
\text { ability to create } \\
\text { innerative } \\
\text { workplace digital } \\
\text { 'work processes, } \\
\text { routines and } \\
\text { products }\end{array}$ \\
\hline
\end{tabular}

\begin{tabular}{|c|c|c|c|c|c|}
\hline $\begin{array}{l}\text { Living in } \\
\text { the } \\
\text { digital } \\
\text { age }\end{array}$ & $\begin{array}{l}\text { Awareness of } \\
\text { digital threats } \\
\text { and the social } \\
\text { and } \\
\text { ernirenmentsl } \\
\text { implications of } \\
\text { digital } \\
\text { tochnologics as } \\
\text { wall as besic } \\
\text { privary and } \\
\text { copyright } \\
\text { provisions }\end{array}$ & $\begin{array}{l}\text { Followicomply with } \\
\text { besic } \\
\text { orgarisational } \\
\text { nies and policies } \\
\text { to protect } \\
\text { hardwars, } \\
\text { software, } \\
\text { ifformation and } \\
\text { systems (for } \\
\text { example, using } \\
\text { arti-vinses and } \\
\text { passwords) }\end{array}$ & $\begin{array}{l}\text { Apply actwanced } \\
\text { tools, techniques } \\
\text { and configurations } \\
\text { to protect } \\
\text { hardware, } \\
\text { sottware, } \\
\text { infomation and } \\
\text { systoms }\end{array}$ & $\begin{array}{l}\text { Ansiyse digital } \\
\text { risks and } \\
\text { complance to } \\
\text { copyright and } \\
\text { privacy to } \\
\text { identity } \\
\text { security } \\
\text { threats and } \\
\text { vulnerabilities }\end{array}$ & $\begin{array}{l}\text { Creabe poicies } \\
\text { and guidelires to } \\
\text { improve digital } \\
\text { security and } \\
\text { orotect copyright } \\
\text { and privacy and } \\
\text { keep up-to-date } \\
\text { with latest } \\
\text { securty, privacy } \\
\text { and copright } \\
\text { developments }\end{array}$ \\
\hline
\end{tabular}

A manner to study users' competence is to match digital behavior to day-a-day University conduct with the aim of ranking to which extent the users are capable to integrate the digital dimension with other skills such as interpersonal relationships or autonomy and comprehension skills (Buffardi \& Tadeo, 2017). These skills are key in the world of work based on the new wave of digitization that is disrupting all industries and will reshape the way we conceive the world and work in it (Ballestar et al., 2020)

As stated in the introduction, the arrival of COVID-19 and the consequent global pandemic has made digital skills a focus of study and its importance and relevance grow globally. As it was a confinement situation in which university classes had to switch to digital form from one day to the next, this meant that students had a need to possess digital skills to keep up with the pace of learning and work that universities have 
established. Online and offline world should complement each other in education, and digital learning has gained much presence since the COVID-19 situation (Vukic, 2020).

Next, the two hypotheses supported by the existing literature will be formulated, which will be presented in the next section on the methodology and results.

Because COVID-19 and its confinement has caused a disruption in the models of university education, taking education to the remote option, this has led to the rapid development of digital skills among students (Krishnamurthy, 2020). However, Xie, Zang \& Ponzoa (2020) show that during the COVID-19 pandemic, university students have experienced a negative impact on their psychology due to excess information on the internet, social networks and poorly controlled digitization. Undergraduate students, who are younger (in almost all cases) and have less critical thinking, are more inclined to not correctly manage this information and therefore not to fully develop the digital skills of an online education and relationships.

Marchiori \& Franco (2020) said that formal plus informal networks play a key role in the process of knowledge sharing and contributing to each other's personal development, and Master students have this informal network more developed and increased due to their age, specialization and learning interest. With this, we can elaborate our first hypothesis of the study:

Hypothesis 1: Master's business students have developed more digital skills than undergraduate students during the COVID-19 lockdown scenario

As mentioned, it is being studied that during the COVID-19 pandemic a correlation has been created between the prolonged use of some online learning tools and the improvement of their digital skills (Elhai et al., 2020) But, there are some young people who during the pandemic have been attracted by an increase in online gaming and e-sports (López-Cabarcos et al., 2020). This has reduced their grades for university subjects and, therefore, so has their personal development of digital skills such as autonomy, organization and ability to concentrate. (Rampersad, 2020). Moreover, Soares \& Mosquera (2020) argued that international development experiences of students as for example having achieved Erasmus programmes, has a positive effect in the development of managerial, leadership and critical skills. These students are also usually characterized by having higher average grades and making better use of their time and their capacity for organization, autonomy and self-management. This leads us to enact our second study hypothesis:

Hypothesis 2: Business students with higher average transcripts have developed more digital skills during the COVID-19 lockdown scenario.

\section{RESEARCH RESULTS AND DISCUSSION}

The methodology of the present study will be focused on answering the research question, that is: how the digital competences are managed during a period of crisis in a business school context. The period of crisis chosen in this case is the one that we are going through, that is the COVID-19 pandemic.

\subsection{Sample}

The sample will be composed by students from a Spanish prestigious business school. Specifically, our sample is made of students from three different degrees and three master degrees. Regarding the degrees they are focused on marketing management, communication and public relations, and International Business. The master degrees are centered on the development of business skills and tools, the competence study and global marketing. Thus, the students' education is in any case related to companies and business world.

Regarding the characteristics of the sample, the following Table 2 represents some of the most important features:

Table 2: Data collection classification

\begin{tabular}{|c|c|c|c|c|c|}
\cline { 3 - 6 } \multicolumn{2}{c|}{} & Men (\%) & Women (\%) & Age & Average grade \\
\hline \multirow{3}{*}{ Degrees } & Marketing Management & 60 & 40 & 19 & 8,1 \\
\cline { 2 - 7 } & Communication and public relations & 57 & 43 & 18 & 6,5 \\
\hline
\end{tabular}


Proceedings of INTCESS 2021 8th International Conference on Education and Education of Social Sciences 18-19 January, 2021

\begin{tabular}{|c|c|c|c|c|c|}
\hline & International business & 44 & 56 & 20 & 5,5 \\
\hline Master degrees & Business skills & 40 & 60 & 24 & 8,5 \\
\cline { 2 - 6 } & Competence study & 55 & 45 & 24 & 7,2 \\
\cline { 2 - 6 } & Global marketing & 46 & 54 & 25 & 8,3 \\
\hline
\end{tabular}

Regarding the number of women and men, in every case the percentages are around $50 \%$. Thus, the sample is heterogeneous in terms of gender. About the age, the average age in masters' degree is higher than in the degree, which is common since studying the masters' degree requires the previous study of the degree. The same conclusion can be extrapolated to the average grade, students of marsters have passed a previous degree so, there is a natural filter for good students.

\subsection{Scale}

To measure the digital competences, we are going to use a scale that will be validated after the data treatment. The scale has been built following two different sources. The first one of them is the article by CRUE (2012), in which the most important competences related to informatics are highlighted. The second source is the document from the Official Publications Office from the European Community. The scale will be composed by 10 items. The items selected will be the following:

- Driving of the tools following instructions. This item measures the extent to which an individual can not just driving but also interpreting the results obtained through the use of the digital tool.

- Autonomy. It assesses the range of independence in using the technical tools. That is, if the student can utilize the different tools by his/her own or if another person is needed.

- Using help and tutorials. Like in the previous item, this one measures if an inidividual needs help or not to using the technical tools. The difference lies in the help in itself. While in the previous item the help would come from a person, in this case comes from tutorials.

- Reproducing the steps followed. In this case, this item measures if a person can follow a set of steps previously seen. That is, if the person can reproduce the stages followed to achieve the goal.

- Identifying, selecting and combining the necessary tools. This item measures the extent to which a student can get a goal. If he/she can follow the right process using the technical tools necessary to get a final goal.

- Working collaboratively. In this case, what is being measured is if the student knows how to use the technical tools in a group context.

- Attractive presentations. This item assesses if the student knows how to use the right tools to do presentations that can have a positive effect on the spectator's attention.

- Formally correct documents. This item is focused on the selection and development of the tools necessary to do documents that are good in formal terms.

- Focusing capacity. This item measures the extent to which the student uses the technical tools for academic purposes.

- Specific programs. In this item the knowledge of each of the technical tools is measured. That is, the level and depth in which any of the tools is known.

Each one of the aforementioned items will be measured using a Likert scale of ten points.

After the collection of the data we are going to use the SPSS program in order to analyze it. First of all, an exploratory factor analysis will be applied to the different items. By doing so we will be able to group the different items. Further, the analysis will show if there are other possible constructs not measured and if some of the items are not necessary.

Later, once done it the analysis, the next steps will be addressed to test th on the one hand if the better 
knowledge on technical tools is correlated with the master degree and if is also correlated with higher grades. To do this, we are going to use two independent variables and a dependent one.

\subsection{Variables}

Dependent variable. The dependent variable will be the knowledge in technical tools. That will be measured, as was mentioned, by the scale explained in the previous section.

Independent variables.

Level of education. This variable is a dichotomous one. It is composed by two possible values, the first one corresponds to students of degrees and the second one to students of master degrees.

Grades. This variable is a continuous one. It may contain values from 0 to 10 . It collects the average grade of the students through the real degree or master degree.

\subsection{Control Variables}

Gender. This is a dichotomous variable. It watches at the sex of the individuals.

Age. This is a continuous variable. It measures how old the individual is.e two hypotheses proposed. For testing both hypotheses we are going to use correlations.

\section{CONCLUSIONS, PROPOSALS, RECOMMENDATIONS}

Although at this time no definitive conclusions can be drawn from this study, we are going to carry out a series of competencies expected from it.

It is expected that master's students have developed more skills related to digital skills than undergraduate students, due to: intensive use of computer applications in the academic world, greater ability to adapt to changing environments, greater experience effect and autonomous ability to learning, greater maturity, and a higher overall average grade in master's degrees than in degrees.

Also, some boundaries inherent to an exploratory study such as this one must be established. Regarding the limitations that our work may encounter, we found that, in the first place, the study was carried out only at three degrees and three masters of the business school. On the other hand, the fact that it is a business school, and not another typology or another university. If it had been carried out at more or different degrees, as well as in another university or school, the data collected and, therefore, the results, could also vary.

As future steps, we must now choose a methodology and continue with it by conducting the study to see if the expected conclusions are final. Therefore, we will analyze how the development of digital skills has been in bachelor's and master's degree business students to see how business school can help students improve their learning capacity. This will provide a new approach to teachers' classes in which the student will be the center of the methodology and will be able to develop to the maximum, with the aim of being better prepared for the world of work and the post-COVID-19 world.

\section{REFERENCE LIST}

Ballestar, M. T., Díaz-Chao, Á., Sainz, J., Torrent-Sellens, J, 2020. Knowledge, Robots And Productivity In Smes: Explaining The Second Digital Wave. Journal Of Business Research, 108, 119-131.

Battro, A. M., 2004. Digital Skills, Globalization, And Education. Globalization: Culture And Education In The New Millennium, 78-96.

Buffardi, A., Taddeo, G., 2017. The Web 2.0 Skills Of Italian Students: An Empirical Study In Southern Italy. Italian Journal Of Sociology Of Education, 9, 1.

Conferencia De Rectores De Las Universidades Españolas, 2012. Competencias Informáticas E Informacionales (CI2) En Los Estudios De Grado. Madrid: CRUE-TIC-REBIUN.

Dhiman, P., Arora, S., 2020. A Conceptual Framework For Identifying Key Employee Branding Dimensions: A Study Of Hospitality Industry. Journal Of Innovation \& Knowledge, 5, 200-209. 
Elhai, J. D., Yang, H., Mckay, D., Asmundson, G. J., 2020. COVID-19 Anxiety Symptoms Associated With Problematic Smartphone Use Severity In Chinese Adults. Journal Of Affective Disorders.

Gekara, V., Snell, D., Molla, A., Karanasios, S., Thomas, A., 2019. Skilling The Australian Workforce For The Digital Economy. Research Report. National Centre For Vocational Education Research (NCVER).

livari, N., Sharma, S., Ventä-Olkkonen, L., 2020. Digital Transformation Of Everyday Life-How COVID-19 Pandemic Transformed The Basic Education Of The Young Generation And Why Information Management Research Should Care?. International Journal Of Information Management, 102183.

Krishnamurthy, S., 2020. The Future Of Business Education: A Commentary In The Shadow Of The Covid19 Pandemic. Journal Of Business Research.

Lara, F. J., Mogorrón-Guerrero, H., \& Ribeiro-Navarrete, S., 2020. Knowledge Of Managerial Competencies: Cross-Cultural Analysis Between American And European Students. Economic Research-Ekonomska Istraživanja, 33, 2059-2074.

López-Cabarcos, M. Á., Ribeiro-Soriano, D., Piñeiro-Chousa, J., 2020. All That Glitters Is Not Gold. The Rise Of Gaming In The COVID-19 Pandemic. Journal Of Innovation \& Knowledge.

Marchiori, D., \& Franco, M., 2020. Knowledge Transfer In The Context Of Inter-Organizational Networks: Foundations And Intellectual Structures. Journal Of Innovation \& Knowledge, 5, 130-139.

Morrison, C., \& Rooney, L., 2017. Digital Skills For The UK Economy.

Orero-Blat, M., Simón-Moya, V., Guerrero, H. M., Carrubi, D. B., \& Sendra, J. (2020, June). Client Orientation In Fashion E-Commerce: A Comparative Study. In 2020 15th Iberian Conference On Information Systems And Technologies (CISTI), 1-6. IEEE.

Rampersad, G., 2020. Robot Will Take Your Job: Innovation For An Era Of Artificial Intelligence. Journal Of Business Research, 116, 68-74.

Riel, J., Christian, S., Hinson, B., 2012. Charting Digital Literacy: A Framework For Information Technology And Digital Skills Education In The Community College. Available At SSRN 2781161.

Soares, M. E., Mosquera, P., 2020. Linking Development Of Skills And Perceptions Of Employability: The Case Of Erasmus Students. Economic Research-Ekonomska Istraživanja, 33(1), 2769-2786.

Sponberg, H., 1995. Distance Education At The College Of Gjøvik. In Innovative Adult Learning With Innovative Technologies, 207-211. Elsevier Science Inc.

Unión Europea, 2007. Competencias Clave Para El Aprendizaje Permanente. Un Marco De Referencia Europeo. Luxemburgo: Oficina De Publicaciones Oficiales De Las Comunidades Europeas.

Vieru, D., 2015. Towards A Multi-Dimensional Model Of Digital Competence In Small-And Medium-Sized Enterprises. In Encyclopedia Of Information Science And Technology, Third Edition, 6715-6725. IGI Global. 